\title{
Effect of Some Fertilization Treatments on Growth, Yield, Fruit Quality and Nutritional Status of Banana Grande Naine Cultivar
}

\author{
H. E. M. El-Badawy * and Maha M. E. Ali** \\ * Hort. Dept., Fac. Agric., Benha Univ., Egypt. \\ ** Soils and water Dept., Fac. Agric., Benha Univ., Egypt. \\ Corresponding author: Hamed.albadawy@fagr.bu.edu.eg, h.elzaabalawy@yahoo.com
}

\begin{abstract}
This work was carried out at the sandy soil of El-Khatatba region, Minofia Governorate, Egypt, through the two successive seasons of 2016 and 2017 to study the effect of organic fertilization combined with chemical fertilizer in presence of bio fertilizer on growth, yield, quality and nutritional status of banana Grande Naine cultivar. Mother plants were planted at $3 \times 2 \mathrm{~m}$ apart in March 2015 and two suckers were selected per each hole and the others were removed. The obtained results showed that, the highest values of pseudostem height, pseudostem circumference, leaf area and assimilation area per plants were scored by $\mathrm{T}_{1}$ recommended dose of chemical fertilization (RD), followed in descending order by $\mathrm{T}_{4}$ treatment $(75 \% \mathrm{RD}+21 \mathrm{~kg}$ compost $+5 \mathrm{ml}$ bio./plant) with non-significant differences between them in the two seasons. The highest values of bunch length, fruits yield per fed., the thickest bunch, the heaviest bunch, the highest number of fingers/hand and the heaviest hand were scored by $\mathrm{T}_{1}$ treatment, followed in descending order by $\mathrm{T}_{4}$ treatment in the two seasons. The highest values of finger length, finger diameter and finger weight as well as the richest fruit pulp total sugars $\%$ and T.S.S. $\%$ were recorded by $\mathrm{T}_{4}$, followed by $\mathrm{T}_{7}(75 \% \mathrm{RD}+45 \mathrm{~g}$ humic $+5 \mathrm{ml}$ bio./plant $)$ in the two seasons. The heaviest pulp weight was obtained by those received $\mathrm{T}_{4}$ treatment, followed in descending order by $\mathrm{T}_{7}$ treatments, whereas the highest pulp/peel ratio was registered by $\mathrm{T}_{7}$ and $\mathrm{T}_{4}$ treatments in the two seasons. Banana plants received the full dose of chemical fertilization (100\% RD) is being the most promising one for inducing the greatest leaf total carbohydrates, $\mathrm{N}, \mathrm{P}$ and $\mathrm{K}$ percentage, followed in descending order by $\mathrm{T}_{4}$ and $\mathrm{T}_{7}$ treatments without significant difference between them in the two seasons.
\end{abstract}

Key words: Banana, chemical, organic, bio- fertilization, growth, yield, fruit quality and nutritional status.

\section{Introduction}

Banana (Musa spp) member of the Musaceae family is one of the most important tropical fruit crops in the world and is major tropical food crop (Sharrock et al., 2001). Banana fruit is important source of nutrients containing polysaccharides, sugars, vitamins $\mathrm{A}, \mathrm{C}, \mathrm{B}_{6}$ and other minerals with traces of fat as well as beneficial health properties and reduced risk for some forms of cancer, heart disease, stroke and other chronic ailments due to the presence of antioxidants and biologically active ingredients (Hui et al., 2006 and Park et al., 2011). Banana cv. Grande Naine is a popular variety grown mostly in all export oriented countries of Asia, South America and Africa.

Organic agriculture is an ecological management system that promotes and enhances biodiversity, biological cycles and soil biological activates. It is based on the minimal use of chemical inputs and management practices that restore maintain and enhance ecological harmony. Therefore, a great attention has been paid to use the natural source of nutrition as an alternative to the mineral fertilization, but organic fruit growers have little experience with banana plants.

Compost is a readily available fertilizer with beneficial effects on physical, chemical, biochemical and biological properties of the soils. Moreover, compost-based treatments stimulate an enhanced plant physiological status with improvements in quantity and quality of crop productions (Zaccardelli et al., 2012).

Humic substances are recognized as a key component of soil fertility properties, since they control the chemical and biological properties of the rhizosphere. Humic acid (polymeric polyhydroxy acid) is highly beneficial to both plant and soil; it is important for increasing microbial activity, it is considered as a plant growth bio-stimulant and an effective soil enhancer; it promotes nutrient uptake as chelating agent (Nardi et al., 2005). Also, it improves vegetative characteristics, nutritional status and leaf pigments (Eissa-Fawzia et al., 2007 and Ismail et al., 2007).

Chemical fertilization is an important and limiting factor for growth and production of banana plants because plants remove large amounts of nutrients from the soil. Among these nutrients, nitrogen, phosphorus and potassium are considered the prime nutrients for growth of plants. For growth and fruit production, bananas require high amounts of nutrients which are often supplied only in part by the soil. These nutrients have to be enriched with organic and bio fertilizers in order to maintain soil fertility and to permit the continuous production of high yields (Gowen, 1995). Several investigators recoded that combined application of inorganic 
fertilizers with organic or bio fertilizers decreased soil $\mathrm{pH}$ and increased soil $\mathrm{N}, \mathrm{P}$ and $\mathrm{K}$ availability (Russo and Berlyn, 1990; Suresh et al., 2004; Gogoi et al., 2004 and Coker, 2006) and improved growth, yield and fruit quality of banana plants (Abd El-Naby and El Sonbaty, 2005; Abdel MoneimEman et al., 2008; Vazquez-Ovando et al., 2012; Al-Busaidi, 2013 and Baiea and El-Gioushy, 2015).

Bio-fertilization is considered an important tool to enhance the yield and fruit quality of fruit trees and it becomes, as positive alternative to chemical fertilizers. It is safe for human and environmental and using it was accompanied with reducing the great pollution occurred on our environment as well as for producing organic foods for export (Abdelaal et al., 2010).

With this background, an experiment was undertaken to know the effect of compost and humic acid as a source of organic fertilization combined with chemical fertilizer in presence of bio fertilizer comparing with the full dose of chemical fertilizer on growth, yield, quality and chemical constituents of banana cv. Grande Naine grown under sandy soil conditions.

\section{Materials and Methods}

This work was carried out at the sandy soil of ElKhatatba region, Minofia Governorate, Egypt, through the two successive seasons of 2016 (first ratoon plants) and 2017 (second ratoon plants) to study the effect of organic fertilization combined with chemical fertilizer in presence of bio fertilizer on growth, yield, quality and nutritional status of banana Grande Naine cultivar, Giant Cavendish AAA sub-group grown under sandy soil conditions. Mother plants were planted in March, 2015. Mats (plantation holes) were $3 \times 2 \mathrm{~m}$ apart with two productive ratoons per each (two suckers were annually selected and remained to grow for the consecutive cropping). The suckers devoted for this study were healthy, nearly unisource in growth vigor and received regularly the recommended horticultural practices, hence every Fadden contains 1400 plants. The chemical and mechanical properties of the used soil are presented in Table, 1 .

Table 1. Soil characteristics of banana plantation at the start of the experiment.

\begin{tabular}{lccccc}
\hline Mechanical analysis & Value & Chemical analysis & Value & Anion and Cation (Meq/I) & Value \\
\hline Coarse sand\% & 48.3 & $\mathrm{CaCO} \%$ & 2.11 & $\mathrm{Ca}^{++}$ & 1.81 \\
Fine sand\% & 36.7 & Field capacity\% & 14.3 & $\mathrm{Na}^{+}$ & $\mathrm{Mg}^{+}$ \\
Silt\% & 12.4 & $\mathrm{PH}$ & 7.82 & $\mathrm{~K}^{+}$ & 0.86 \\
Clay\% & 2.6 & Organic matter\% & 0.36 & $\mathrm{CO}_{3}^{--}$ & 0.21 \\
Soil texture & Sandy & EC (ds/m) & 0.48 & $\mathrm{HCO}_{3}^{-}$ & 0.0 \\
& & Total N\% & 0.13 & $\mathrm{Cl}^{-}$ & 2.49 \\
& & & $\mathrm{SO}_{4}^{--}$ & 1.52 \\
\end{tabular}

The experimental plants received all the agricultural practices usually used in banana plantation, except for the purpose of this study. The main source of water supply was well water under drip irrigation.

\section{Chemical fertilizer treatments}

Chemical fertilizers doses were added through drip irrigation system during the two seasons of this study. The plants were received chemical fertilizers at the recommended doses of chemical NPK $(800$, $100,1000 \mathrm{~N}, \mathrm{P}_{2} \mathrm{O}_{5}$ and $\mathrm{K}_{2} \mathrm{O}$ actual $\mathrm{Kg} / \mathrm{fed}$ ) in the forms of ammonium nitrate $33.5 \mathrm{~N} \%$, phosphoric acid $80 \%\left(\mathrm{P}_{2} \mathrm{O}_{5}\right)$ and potassium sulphate $48 \%\left(\mathrm{~K}_{2} \mathrm{O}\right)$ (National campaign for improving banana productivity in Egypt, 2014).

\section{- Organic fertilizer treatments}

Organic fertilizer (compost) at the rate of 7, 14 and $21 \mathrm{~kg}$ per plant/year were added in early December of both seasons. Two trenches $(100 \times 50 \times 50 \mathrm{~cm})$ were excavated on the two side of the plant, and then the given amount of compost as a part of surface soil was mixed together and added to the chuck holes followed by irrigation. Chemical analysis of used compost are shown in Table, 2 .

Humic acid (potassium humate) at the rate of 15 , 30 and $45 \mathrm{~g}$ per plant/year, where the rates were divided into equal two doses and added as soil drench just before irrigation at March $1^{\text {st }}$ and May $1^{\text {st }}$. Humic fertilizer analysis: Humic acid $75 \%$, potassium $\left(\mathrm{K}_{2} \mathrm{O}\right) 10 \%$, volvic acid $4 \%$ and $\mathrm{Fe} 2 \%$.

Table 2. Chemical analysis of the used compost

\begin{tabular}{cccccccccc}
\hline $\begin{array}{c}\text { Parameters } \\
\text { Determinations }\end{array}$ & $\begin{array}{c}\text { Ec } \\
(\mathbf{d s} / \mathbf{m})\end{array}$ & $\mathbf{p H}$ & $\mathbf{C} \%$ & $\mathbf{N} \%$ & $\mathbf{P} \%$ & $\mathbf{K} \%$ & $\begin{array}{c}\mathbf{F e} \\
(\mathbf{p p m})\end{array}$ & $\begin{array}{c}\mathbf{Z n} \\
(\mathbf{p p m})\end{array}$ & $\begin{array}{c}\mathbf{C}: \mathbf{N} \\
\text { ratio }\end{array}$ \\
\hline Values & 3.68 & 6.89 & 19.54 & 1.08 & 0.47 & 1.39 & 1419 & 222 & $18: 1$ \\
\hline
\end{tabular}

All banana plants which received organic fertilizer were inoculated with a mixture of nitrobein
+ phosphorein contained efficient strains of nitrogen fixing bacteria namely, Azotobacter chroococcum + 
phosphate dissolving bacteria (Bacillus megaterium var phosphaticum) which supplied by the Department of Microbiology, Agric. Res. Center, Giza was used in this study as biological activators. The strains were characterized by a good ability to infect its specific host plant and by its high efficiency in $\mathrm{N}$-fixation and phosphate solubilizing. Banana pants received bio fertilizer as soil drench at the rate of $5 \mathrm{ml} /$ plant in March $1^{\text {st }}$.

Table 3. The experiment consisted of seven treatments as follows

\begin{tabular}{|c|c|c|c|c|c|c|}
\hline \multirow[t]{2}{*}{ Treatments } & \multicolumn{3}{|c|}{$\begin{array}{c}\text { Chemical fertilization } \\
\text { (g/plant/year) }\end{array}$} & \multirow{2}{*}{$\begin{array}{c}\text { Compost } \\
\text { (kg/plant } \\
\text { /year) }\end{array}$} & \multirow{2}{*}{$\begin{array}{l}\text { Humic acid } \\
\text { (g/plant/year) }\end{array}$} & \multirow{2}{*}{$\begin{array}{c}\text { Bio- } \\
\text { fertilization } \\
\text { (ml/plant/year) }\end{array}$} \\
\hline & $\mathbf{N}$ & $\mathbf{P}$ & $\mathbf{K}$ & & & \\
\hline$\left(\mathrm{T}_{1}\right) \mathbf{1 0 0 \%}$ Chemical fertilizers (RD) & 571 & 71 & 714 & -------- & ------- & -------- \\
\hline$\left(\mathrm{T}_{2}\right) 75 \% \mathrm{RD}+7 \mathrm{~kg}$ compost $+5 \mathrm{ml}$ bio./plant & 428.6 & 53.6 & 535.7 & 7 & -------- & 5 \\
\hline ( $\left.\mathrm{T}_{3}\right) 75 \% \mathrm{RD}+14 \mathrm{~kg}$ compost $+5 \mathrm{ml}$ bio./plant & 428.6 & 53.6 & 535.7 & 14 & -------- & 5 \\
\hline ( $\left.\mathrm{T}_{4}\right) 75 \% \mathrm{RD}+21 \mathrm{~kg}$ compost $+5 \mathrm{ml}$ bio./plant & 428.6 & 53.6 & 535.7 & 21 & -------- & 5 \\
\hline (T5) $75 \%$ RD+15g humic $+5 \mathrm{ml}$ bio./plant & 428.6 & 53.6 & 535.7 & -------- & 15 & 5 \\
\hline (T6) $75 \%$ RD+30g humic +5ml bio./plant & 428.6 & 53.6 & 535.7 & -------- & 30 & 5 \\
\hline$\left(\mathrm{T}_{7}\right) \mathbf{7 5 \%} \mathrm{RD}+\mathbf{4 5 g}$ humic $+5 \mathrm{ml}$ bio./plant & 428.6 & 53.6 & 535.7 & -------- & 45 & 5 \\
\hline
\end{tabular}

\section{Recorded data}

\section{Vegetative growth}

Pseudostem height $(\mathrm{cm})$, pseudostem circumference $(\mathrm{cm})$, leaves number per plant, leaf length $(\mathrm{cm})$, leaf width $(\mathrm{cm})$ and leaf area $\left(\mathrm{m}^{2}\right)$ of the third full sized leaf (from the top) was calculated using the equation $=$ leaf length $(\mathrm{cm}) \times$ leaf width $(\mathrm{cm}) \times 0.8$ (Murry, 1960) and assimilation area per plant $\left(\mathrm{m}^{2}\right)$ was determined using the equation= leaf area $\times$ number of green leaves (Ibrahim, 1993). Vegetative growth measurements were taken at bunch shooting stage.

\section{Yield parameters}

The bunches were harvested when the fingers reached the full mature stage as well as when the top hands and fingers become roundish and turned slightly yellow according to Nolin (1985). Bunch length and circumference $(\mathrm{cm})$, bunch weight $(\mathrm{kg})$ and finally mean yield/fed. (ton) was calculated according to the following equation:

Yield $/$ fed. $($ ton $)=$ Bunch weight $(\mathrm{kg}) \times$ Number of plants /fed. (1400 plants) $\times 10^{-3}$.

\section{Fruit physical and chemical characteristics}

Number of fingers/ hand were counted and recorded, hand weight $(\mathrm{kg})$, finger weight $(\mathrm{g})$, finger length and diameter $(\mathrm{cm})$, pulp weight $(\mathrm{g})$, peel weight (g), pulp/ peel ratio, total soluble solids (\%), total sugars (\%), starch (\%) and titratable acidity (\%) were estimated from samples of natural and uniform ripened fruits which taken from the middle portion $\left(5^{\text {th }}\right.$ and $6^{\text {th }}$ ) of two hands for each bunch. Total sugars, starch and titratable acidity were determined according to A.O.A.C (1995).

Nutritional status

Leaf samples were taken from the third upper leaf in the descending foliar succession of the plant at bunch shooting as recommended by Hewitt (1955). Total nitrogen was determined by using microkjeldehl method as described by Pregl (1945).
Phosphorus was estimated according to Evenhuis and Dewaored (1980). Potassium was determined photometrically as described by Brown and Lilleland (1946). Total carbohydrates were determined according to Herbert et al., (1971).

Statistical analysis

The obtained data in both seasons were statistically analyzed using analysis of variance method as a simple experiment in randomized complete blocks design. However, LSD at 0.05 was used to differentiate between means according to Snedecor and Cochran (1980).

\section{Results and Discussion}

\section{1- Vegetative growth parameters}

Data in Table, 4 showed that $\mathrm{T}_{1}(100 \%$ of the recommended dose of chemical fertilizer (RD)) was the most effective treatment for producing the greatest values of the tested vegetative growth parameters as compared with the other treatments in the two seasons. In this concern, the highest values of pseudostem height $(271.8$ and $283.4 \mathrm{~cm})$, pseudostem circumference $(83.4$ and $81.7 \mathrm{~cm})$, leaf area (1.92 and $\left.1.97 \mathrm{~m}^{2}\right)$ and assimilation area per plants $\left(20.43\right.$ and $20.17 \mathrm{~m}^{2}$ ) were scored by $\mathrm{T}_{1}$ followed in descending order by $\mathrm{T}_{4}(75 \% \mathrm{RD}+21 \mathrm{~kg}$ compost $+5 \mathrm{ml}$ bio./plant) with non-significant differences between them in the first and second seasons, respectively. In the reserve, the lowest values of these parameters were gained by $\mathrm{T}_{2}$ treatment $(75 \% \mathrm{RD}+7 \mathrm{~kg}$ compost $+5 \mathrm{ml}$ bio/plant), followed in ascending order by $\mathrm{T}_{5}(75 \% \mathrm{RD}+15 \mathrm{~g}$ humic+ $5 \mathrm{ml}$ bio./plant) in the two seasons. The remained treatments occupied an intermediate position between the above mentioned treatments in the two seasons. However, the differences between number of leaves/plant due to use the tested treatments were not significant in the two seasons.

The obtained results are in concordance with those mentioned by Abd El-Naby (2000), Abd ElNaby and Gomaa (2000) and Solimanm et al., 
(2006) on Maghrabi banana; Tirkey et al., (2002) on Dwarf Cavendish banana; Hammam et al., (2003) and El-Sawy (2005) on Williams banana; DamattoJunior et al., (2007) on Prataana banana (Musa $\mathrm{AAB})$; Al-Busaidi (2013) on Malindi banana and EL-Agamy et al., (2001), Abdel Gawad-Nehad
(2016) and Amin et al., (2016) on Grande Naine banana. In this concern, Baiea and El-Gioushy (2015) showed that chemical fertilizers of NPK $(100 \%)+$ compost + humic + EM (effective microorganisms) increased vegetative growth of Grande Naine banana plants.

Table 4. Effect of some fertilization treatments on some vegetative growth parameters of banana cv. Grande Naine during 2016 and 2017 seasons.

\begin{tabular}{|c|c|c|c|c|c|c|c|c|c|c|}
\hline \multirow[b]{2}{*}{ Treatments } & \multicolumn{2}{|c|}{$\begin{array}{c}\text { Pseudo } \\
\text { stem } \\
\text { height }(\mathbf{c m}) \\
\end{array}$} & \multicolumn{2}{|c|}{$\begin{array}{l}\text { Pseudo stem } \\
\text { circumference } \\
(\mathrm{cm})\end{array}$} & \multicolumn{2}{|c|}{$\begin{array}{c}\text { No. of } \\
\text { leaveslplant }\end{array}$} & \multicolumn{2}{|c|}{$\begin{array}{c}\text { Leaf area } \\
\qquad\left(\mathbf{m}^{2}\right)\end{array}$} & \multicolumn{2}{|c|}{$\begin{array}{c}\text { Assimilation } \\
\text { area/plant } \\
\left(\mathbf{m}^{2}\right)\end{array}$} \\
\hline & 1st & 2nd & 1st & $2 \underline{\text { nd }}$ & 1 st & $2 \underline{\text { nd }}$ & 1st & 2nd & 1st & $2 \underline{\text { nd }}$ \\
\hline $\begin{array}{l}\left(\mathrm{T}_{1}\right) \mathbf{1 0 0 \%} \text { Chemical fertilizers } \\
\text { (RD) }\end{array}$ & 271.8 & 283.4 & 83.4 & 81.7 & 10.64 & 10.24 & 1.92 & 1.97 & 20.43 & 20.17 \\
\hline $\begin{array}{l}\left(\mathrm{T}_{2}\right) 75 \% \mathrm{RD}+7 \mathrm{~kg} \text { compost }+5 \mathrm{ml} \\
\text { bio./plant }\end{array}$ & 246.4 & 259.2 & 68.7 & 67.8 & 10.29 & 10.19 & 1.71 & 1.76 & 17.59 & 17.93 \\
\hline $\begin{array}{l}\left(\mathrm{T}_{3}\right) 75 \% \mathrm{RD}+14 \mathrm{~kg} \text { compost }+5 \mathrm{ml} \\
\text { bio./plant }\end{array}$ & 263.2 & 268.0 & 76.4 & 74.9 & 10.31 & 10.36 & 1.82 & 1.81 & 18.76 & 18.75 \\
\hline $\begin{array}{l}\left(\mathrm{T}_{4}\right) 75 \% \mathrm{RD}+21 \mathrm{~kg} \text { compost }+5 \mathrm{ml} \\
\text { bio./plant }\end{array}$ & 268.6 & 276.9 & 81.1 & 79.2 & 10.29 & 10.32 & 1.86 & 1.92 & 19.14 & 19.81 \\
\hline $\begin{array}{l}\left(\mathrm{T}_{5}\right) 75 \% \mathrm{RD}+15 \mathrm{~g} \text { humic }+5 \mathrm{ml} \\
\text { bio./plant }\end{array}$ & 248.1 & 261.3 & 69.8 & 69.1 & 10.26 & 10.24 & 1.76 & 1.81 & 18.06 & 18.53 \\
\hline $\begin{array}{l}\text { (T) } 75 \% \text { RD+30g humic }+5 \mathrm{ml} \\
\text { bio./plant }\end{array}$ & 264.8 & 266.9 & 75.8 & 75.3 & 10.36 & 10.21 & 1.81 & 1.84 & 18.75 & 18.79 \\
\hline $\begin{array}{l}\text { (T) } 75 \% \text { RD+45g humic }+5 \mathrm{ml} \\
\text { bio./plant }\end{array}$ & 267.0 & 274.6 & 79.9 & 78.6 & 10.34 & 10.38 & 1.82 & 1.89 & 18.82 & 19.62 \\
\hline L.S.D at $0.05 \%$ & 12.6 & 14.1 & 9.41 & 8.36 & N.S & N.S & 0.11 & 0.12 & 1.38 & 0.49 \\
\hline
\end{tabular}

\section{2- Yield parameters}

Data presented in Table, 5 revealed that the highest values of bunch length was scored by $T_{1}$ treatment, followed in descending order by $\mathrm{T}_{4}$ treatment in the two seasons of study. Moreover, $\mathrm{T}_{7}$ and $\mathrm{T}_{3}$ treatments showed high increments in this concern in the two seasons. The differences between the aforementioned four treatments were not significant in the two seasons, except for $T_{3}$ treatment in the first season. The thickest bunch was registered by $\mathrm{T}_{4}$-fertilized banana plants, followed in descending order by $\mathrm{T}_{7}$ and $\mathrm{T}_{1}$-fertilized banana plants, with non-significant differences between them in the two seasons. While, the heaviest bunch was scored by $T_{1}$ treatment, followed by $T_{4}$ and $T_{7}$ treatments, with non-significant differences between them in the two seasons.

In general, the highest yield of banana cv. Grande Naine was scored by $\mathrm{T}_{1}$ treatment (45.93 and 46.84 ton/fed), followed in descending order by $\mathrm{T}_{4}$ treatment (43.78 and 45.86 ton/fed) and $\mathrm{T}_{7}$ treatment (43.37 and 45.20 ton/fed) in the first and second seasons, respectively. The differences between the above mentioned three treatments did not reach to the level of significance in the two seasons. In the contrast, the lowest banana yield was gained by $T_{2}$ treatment (36.62 and 36.26 ton/fed), followed in ascending order by $\mathrm{T}_{5}$ (38.98 and 37.42 ton/fed) treatment in the first and second seasons, respectively. The other treatments came in between the aforesaid treatments in the two seasons.

These results are in agreement with those obtained by Abd El-Naby (2000), Abd El-Naby and Gomaa (2000), Athani and Hulamani (2000), EL-Agamy et al., (2001), Ayuso (2002), Tirkey et al., (2002), Abd El-Naby and El Sonbaty (2005), El-Sawy (2005), Solimanm et al., (2006), DamattoJunior et al., (2007), EL-Shenawi et al., (2008), Hammam et al., (2003), Barakat et al., (2011), AlBusaidi (2013), Bakheit and Elsadig (2015), Abdel Gawad-Nehad (2016), Hema et al., (2016) and Sangeeta et al., (2017) on different banana cultivars. In this regard, Baiea and El-Gioushy (2015) reported that Grande Naine banana plants received $100 \%$ chemical fertilizers of NPK + compost + humic + EM increased bunch length, bunch circumference, bunch weight and total yield. Furthermore, increasing amount of organic manures and humic acid increased yield of Grande Naine and Williams banana plants, respectively (Abdel Moneim-Eman et al., 2008 and Amin et al., 2016). 
Table 5. Effect of some fertilization treatments on yield parameters of banana cv. Grande Naine during 2016 and 2017 seasons.

\begin{tabular}{|c|c|c|c|c|c|c|c|c|}
\hline \multirow[b]{2}{*}{ Treatments } & \multicolumn{2}{|c|}{$\begin{array}{c}\text { Bunch length } \\
(\mathrm{cm})\end{array}$} & \multicolumn{2}{|c|}{$\begin{array}{c}\text { Bunch } \\
\text { circumference } \\
(\mathbf{c m})\end{array}$} & \multicolumn{2}{|c|}{$\begin{array}{c}\text { Bunch weight } \\
(\mathrm{kg})\end{array}$} & \multicolumn{2}{|c|}{$\begin{array}{l}\text { Yield/fed. } \\
\text { (ton) }\end{array}$} \\
\hline & 1 st & $2 \underline{\text { nd }}$ & 15t & $2 \underline{\text { nd }}$ & 1st & $2 \underline{\text { nd }}$ & 1st & $2 \underline{\text { nd }}$ \\
\hline$\left(T_{1}\right) 100 \%$ Chemical fertilizers (RD) & 112.6 & 119.4 & 108.7 & 113.4 & 32.81 & 33.46 & 45.93 & 46.84 \\
\hline$\left(\mathrm{T}_{2}\right) 75 \% \mathrm{RD}+7 \mathrm{~kg}$ compost $+5 \mathrm{ml}$ bio./plant & 89.8 & 96.3 & 96.2 & 98.6 & 26.16 & 25.90 & 36.62 & 36.26 \\
\hline$\left(\mathrm{T}_{3}\right) 75 \% \mathrm{RD}+14 \mathrm{~kg}$ compost $+5 \mathrm{ml}$ bio./plant & 96.7 & 104.7 & 104.9 & 109.8 & 29.42 & 30.22 & 41.19 & 42.31 \\
\hline ( $\left.\mathrm{T}_{4}\right) 75 \% \mathrm{RD}+21 \mathrm{~kg}$ compost $+5 \mathrm{ml}$ bio./plant & 108.9 & 112.6 & 112.1 & 117.4 & 31.27 & 32.76 & 43.78 & 45.86 \\
\hline (T5) $75 \% \mathrm{RD}+15 \mathrm{~g}$ humic $+5 \mathrm{ml}$ bio./plant & 94.3 & 98.7 & 98.7 & 101.3 & 27.84 & 26.73 & 38.98 & 37.42 \\
\hline ( $\left.\mathrm{T}_{6}\right) 75 \% \mathrm{RD}+30 \mathrm{~g}$ humic $+5 \mathrm{ml}$ bio./plant & 102.6 & 103.9 & 106.1 & 107.9 & 29.42 & 31.10 & 41.19 & 43.54 \\
\hline$\left(\mathrm{T}_{7}\right) 75 \% \mathrm{RD}+45 \mathrm{~g}$ humic $+5 \mathrm{ml}$ bio./plant & 106.4 & 109.8 & 109.3 & 115.1 & 30.98 & 32.28 & 43.37 & 45.20 \\
\hline L.S.D at $0.05 \%$ & 14.6 & 16.7 & 6.92 & 7.21 & 3.14 & 2.91 & 2.71 & 1.82 \\
\hline
\end{tabular}

\section{3-Fruit physical characteristics}

Data in Tables, 6 and 7 reported that, the highest number of fingers/hand and the heaviest hand were scored by $\mathrm{T}_{1}$ treatment, followed in descending order by $\mathrm{T}_{4}$ and $\mathrm{T}_{7}$ treatments, with non-significant differences between them in the two seasons. The highest values of finger length, finger diameter and finger weights were recorded by $\mathrm{T}_{4}$-fertilized banana plants, followed by $T_{7}$ and $T_{1}$-fertilized plants in the two seasons. The difference between the above mentioned three treatments are very low to reach the level of significance in the two seasons. The heaviest pulp was obtained by those received $\mathrm{T}_{4}$ treatment, followed in descending order by $T_{7}$ and $T_{6}$ treatments, without significant difference between them in the two seasons, while the lowest peel weight was detected by $\mathrm{T}_{6}$ treatment $(75 \% \mathrm{RD}+30 \mathrm{~g}$ humic $+5 \mathrm{ml}$ bio./plant), followed by $\mathrm{T}_{3}$ treatment in the two season. Whereas, the highest pulp/peel ratio was registered by $\mathrm{T}_{7}$ and $\mathrm{T}_{4}$ Treatments in the two seasons.

Table 6. Effect of some fertilization treatments on number of fingers/hand, hand weight $(\mathrm{kg})$, finger length $(\mathrm{cm})$ and finger diameter $(\mathrm{cm})$ of banana cv. Grande Naine during 2016 and 2017 seasons.

\begin{tabular}{|c|c|c|c|c|c|c|c|c|}
\hline \multirow[b]{2}{*}{ Treatments } & \multicolumn{2}{|c|}{$\begin{array}{c}\text { No. of } \\
\text { fingers/hand }\end{array}$} & \multicolumn{2}{|c|}{$\begin{array}{c}\text { Hand weight } \\
\text { (kg) }\end{array}$} & \multicolumn{2}{|c|}{$\begin{array}{c}\text { Finger } \\
\text { length }(\mathbf{c m})\end{array}$} & \multicolumn{2}{|c|}{$\begin{array}{c}\text { Finger } \\
\text { diameter } \\
(\mathrm{cm})\end{array}$} \\
\hline & 1st & 2nd & 1st & $2 \underline{\text { nd }}$ & 1st & 2 $\underline{\text { nd }}$ & 1. & 2 $\underline{\text { nd }}$ \\
\hline$\left(\mathrm{T}_{1}\right) \mathbf{1 0 0 \%}$ Chemical fertilizers (RD) & 21.6 & 23.1 & 2.36 & 2.59 & 18.1 & 17.9 & 3.58 & 3.62 \\
\hline$\left(\mathrm{T}_{2}\right) 75 \% \mathrm{RD}+7 \mathrm{~kg}$ compost $+5 \mathrm{ml}$ bio. $/$ plant & 16.8 & 16.4 & 1.62 & 1.58 & 16.8 & 16.6 & 3.26 & 3.37 \\
\hline$\left(T_{3}\right) 75 \%$ RD+14kg compost $+5 \mathrm{ml}$ bio./plant & 18.4 & 19.1 & 1.92 & 2.12 & 17.9 & 17.8 & 3.42 & 3.64 \\
\hline ( $\left.\mathrm{T}_{4}\right) 75 \% \mathrm{RD}+21 \mathrm{~kg}$ compost $+5 \mathrm{ml}$ bio./plant & 19.2 & 21.3 & 2.30 & 2.56 & 18.7 & 18.9 & 3.74 & 3.84 \\
\hline$\left(\mathrm{T}_{5}\right) 75 \% \mathrm{RD}+15 \mathrm{~g}$ humic+5ml bio./plant & 17.1 & 16.9 & 1.70 & 1.71 & 16.9 & 16.7 & 3.31 & 3.42 \\
\hline ( $\left.\mathrm{T}_{6}\right) 75 \% \mathrm{RD}+30 \mathrm{~g}$ humic+5ml bio./plant & 18.2 & 18.7 & 1.84 & 2.03 & 18.0 & 17.6 & 3.41 & 3.61 \\
\hline$\left(\mathrm{T}_{7}\right) 75 \% \mathrm{RD}+45 \mathrm{~g}$ humic $+5 \mathrm{ml}$ bio./plant & 19.0 & 20.9 & 2.21 & 2.46 & 18.3 & 18.5 & 3.62 & 3.74 \\
\hline L.S.D at $0.05 \%$ & 1.26 & 1.42 & 0.12 & 0.19 & 0.52 & 0.71 & 0.17 & 0.19 \\
\hline
\end{tabular}

Table 7. Effect of some fertilization treatments on finger weight $(\mathrm{g})$, pulp weight $(\mathrm{g})$, peel weight $(\mathrm{g})$ and pulp/peel ratio of banana cv. Grande Naine during 2016 and 2017 seasons.

\begin{tabular}{|c|c|c|c|c|c|c|c|c|}
\hline \multirow{2}{*}{ Treatments } & \multicolumn{2}{|c|}{$\begin{array}{c}\text { Finger } \\
\text { weight } \\
\text { (g) }\end{array}$} & \multicolumn{2}{|c|}{$\begin{array}{c}\text { Pulp weight } \\
\text { (g) }\end{array}$} & \multicolumn{2}{|c|}{$\begin{array}{c}\text { Peel weight } \\
\text { (g) }\end{array}$} & \multicolumn{2}{|c|}{$\begin{array}{l}\text { Pulp/peel } \\
\text { ratio }\end{array}$} \\
\hline & 1st & $2 \underline{\text { nd }}$ & 1st & $2 \underline{\text { nd }}$ & 1 st & $2 \underline{\text { nd }}$ & 1 st & $2 \underline{\text { nd }}$ \\
\hline (T1) $100 \%$ Chemical fertilizers (RD) & 102.4 & 107.2 & 67.3 & 70.5 & 35.1 & 36.7 & 1.91 & 1.92 \\
\hline ( $\left.\mathrm{T}_{2}\right) 75 \% \mathrm{RD}+7 \mathrm{~kg}$ compost $+5 \mathrm{ml}$ bio./plant & 92.6 & 91.3 & 61.2 & 62.9 & 31.4 & 28.4 & 1.95 & 2.21 \\
\hline$\left(\mathrm{T}_{3}\right) 75 \% \mathrm{RD}+14 \mathrm{~kg}$ compost $+5 \mathrm{ml}$ bio./plant & 98.9 & 106.4 & 68.3 & 74.5 & 30.6 & 31.9 & 2.23 & 2.34 \\
\hline ( $\left.\mathrm{T}_{4}\right) 75 \% \mathrm{RD}+21 \mathrm{~kg}$ compost $+5 \mathrm{ml}$ bio./plant & 112.7 & 116.3 & 80.2 & 82.6 & 32.5 & 33.7 & 2.47 & 2.45 \\
\hline ( $\left.\mathrm{T}_{5}\right) 75 \% \mathrm{RD}+15 \mathrm{~g}$ humic $+5 \mathrm{ml}$ bio./plant & 94.3 & 96.2 & 63.2 & 63.5 & 31.1 & 32.7 & 2.03 & 1.94 \\
\hline ( $\left.\mathrm{T}_{6}\right) 75 \% \mathrm{RD}+30 \mathrm{~g}$ humic $+5 \mathrm{ml}$ bio./plant & 97.6 & 103.9 & 68.3 & 72.7 & 29.3 & 31.2 & 2.33 & 2.33 \\
\hline ( $\left.\mathrm{T}_{7}\right) 75 \% \mathrm{RD}+45 \mathrm{~g}$ humic $+5 \mathrm{ml}$ bio./plant & 112.1 & 114.2 & 80.0 & 81.1 & 32.1 & 33.1 & 2.49 & 2.45 \\
\hline L.S.D at $0.05 \%$ & 8.37 & 6.14 & 8.16 & 7.32 & 2.84 & 2.60 & 0.32 & 0.28 \\
\hline
\end{tabular}

\section{4-Fruit chemical characteristics}

Data in Table, 8 pointed out that the richest fruit pulp total sugar $\%$ and T.S.S. \% were scored by those fertilized by $\mathrm{T}_{4}$ treatment, followed in descending order by $\mathrm{T}_{7}$ and $\mathrm{T}_{6}$ treatment without significant differences between them in the two seasons. On contrary, the lowest values of these parameters, were gained by $\mathrm{T}_{1}$ treatment in the two seasons of the 
study. However, the differences between the obtained values of fruit pulp starch and total acidity are out the level of significance in the two seasons.

The obtained results regarding fruit physical and chemical characteristics of banana plants were supported by the findings of Abd El-Naby (2000), Abd El-Naby and Gomaa (2000), Abd El-Naby and El Sonbaty (2005) and Solimanm et al., (2006) on Maghrabi banana; Athani and Hulamani (2000) on Rajapuri banana; Bakheit and Elsadig (2015) on banana Cavendish group (AAA) and Baiea and ElGioushy (2015), Abdel Gawad-Nehad (2016), Amin et al., (2016), Hema et al., (2016) and Sangeeta et al., (2017) on Grande Naine banana. In this sphere, Abdel Moneim-Eman et al., (2008) reported that chemical fruit quality of Williams banana were improved using nitrogen in both organic and mineral sources rather than using nitrogen completely via mineral source only. Organic fertilization by using farm yard manure or banana compost was favorable for enhancing fruit quality in terms of increasing finger weight, total soluble solids $\%$, total sugars $\%$ and decreasing starch $\%$ and total acidity $\%$. The best results of fruits quality were obtained from plants received nitrogen through $50 \%$ banana compost plus $50 \%$ out of the recommended dose of nitrogen mineral source.

Table 8. Effect of some fertilization treatments on fruit chemical characteristics of banana cv. Grande Naine during 2016 and 2017 seasons.

\begin{tabular}{|c|c|c|c|c|c|c|c|c|}
\hline \multirow[t]{2}{*}{ Parameters } & \multicolumn{2}{|c|}{$\begin{array}{c}\text { Fruit pulp } \\
\text { total sugar } \\
\text { content }(\%)\end{array}$} & \multicolumn{2}{|c|}{$\begin{array}{c}\text { Fruit pulp } \\
\text { starch } \\
\text { content }(\%)\end{array}$} & \multicolumn{2}{|c|}{$\begin{array}{c}\text { Fruit pulp } \\
\text { T.S.S } \\
(\%)\end{array}$} & \multicolumn{2}{|c|}{$\begin{array}{c}\text { Fruit pulp } \\
\text { total acidity } \\
(\%)\end{array}$} \\
\hline & 1st & $2 \underline{\text { nd }}$ & 1st & $2 \underline{\text { nd }}$ & 1st & $2 \underline{\text { nd }}$ & 1st & 2 nd \\
\hline$\left(T_{1}\right) 100 \%$ Chemical fertilizers (RD) & 15.27 & 15.13 & 2.36 & 2.27 & 19.24 & 19.03 & 0.41 & 0.39 \\
\hline$\left(\mathrm{T}_{2}\right) 75 \% \mathrm{RD}+7 \mathrm{~kg}$ compost $+5 \mathrm{ml}$ bio. $/$ plant & 15.62 & 15.84 & 2.31 & 2.16 & 19.86 & 20.46 & 0.38 & 0.36 \\
\hline$\left(\mathrm{T}_{3}\right) 75 \% \mathrm{RD}+14 \mathrm{~kg}$ compost $+5 \mathrm{ml}$ bio./plant & 15.59 & 16.17 & 2.14 & 2.21 & 19.79 & 20.17 & 0.39 & 0.38 \\
\hline$\left(\mathrm{T}_{4}\right) 75 \% \mathrm{RD}+21 \mathrm{~kg}$ compost $+5 \mathrm{ml}$ bio./plant & 16.46 & 16.58 & 2.25 & 2.19 & 21.16 & 21.40 & 0.37 & 0.37 \\
\hline (T5) $75 \%$ RD+15g humic $+5 \mathrm{ml}$ bio./plant & 15.68 & 15.97 & 2.16 & 2.14 & 19.92 & 20.52 & 0.37 & 0.37 \\
\hline (T6) $75 \%$ RD+30g humic $+5 \mathrm{ml}$ bio./plant & 15.92 & 15.92 & 2.26 & 2.24 & 20.65 & 20.63 & 0.39 & 0.38 \\
\hline$\left(\mathrm{T}_{7}\right) 75 \% \mathrm{RD}+45 \mathrm{~g}$ humic $+5 \mathrm{ml}$ bio./plant & 16.31 & 16.28 & 2.19 & 2.18 & 20.93 & 21.29 & 0.40 & 0.36 \\
\hline L.S.D at $0.05 \%$ & 0.68 & 0.71 & N.S & N.S & 0.84 & 0.92 & N.S & N.S \\
\hline
\end{tabular}

\section{5- Nutritional status}

Data in Table, 9 demonstrated that banana cv. Grande Naine plants received the full dose of chemical fertilization is being the most promising one for inducing the greatest leaf total carbohydrates, $\mathrm{N}, \mathrm{P}$ and $\mathrm{K}$ percentages, followed in descending order by $T_{4}$ and $T_{7}$ treatments without significant difference between them in the two seasons. On the revers, the lowest values of these parameters were gained by $\mathrm{T}_{2}$ treatment in the two seasons. The rest treatments came in between the aforementioned treatments in the two seasons.

Consequently, it is preferable from the previous results that fertilizing banana plants with the combined treatment between $75 \%$ of chemical fertilizer dose $+21 \mathrm{~kg} \quad$ compost $+5 \mathrm{ml}$ bio. $/$ plant fertilizer for enhancing the yield and quality of this plant. Therefore, the present study strongly admits the use of such treatment to produce fruits with high quality and safe for human health.

Table 9. Effect of some fertilization treatments on leaf total carbohydrates N, P and K (\%) of banana cv. Grande Naine during 2016 and 2017 seasons.

\begin{tabular}{|c|c|c|c|c|c|c|c|c|}
\hline \multirow[t]{2}{*}{ Treatments } & \multicolumn{2}{|c|}{$\begin{array}{c}\text { Leaf total } \\
\text { carbohydrates } \\
\text { content } \\
(\%) \\
\end{array}$} & \multicolumn{2}{|c|}{$\begin{array}{l}\text { Leaf } \mathbf{N} \\
\text { content } \\
(\%)\end{array}$} & \multicolumn{2}{|c|}{$\begin{array}{l}\text { Leaf P } \\
\text { content } \\
(\%)\end{array}$} & \multicolumn{2}{|c|}{$\begin{array}{c}\text { Leaf K } \\
\text { content } \\
(\%)\end{array}$} \\
\hline & 1 st & 2nd & 1st & $2 \underline{\text { nd }}$ & 1st & 2nd & 1st & 2nd \\
\hline$\left(\mathrm{T}_{1}\right) \mathbf{1 0 0 \%}$ Chemical fertilizers (RD) & 21.62 & 20.84 & 2.74 & 2.81 & 0.24 & 0.28 & 3.69 & 3.56 \\
\hline$\left(\mathrm{T}_{2}\right) 75 \% \mathrm{RD}+7 \mathrm{~kg}$ compost $+5 \mathrm{ml}$ bio. $/$ plant & 18.11 & 19.79 & 2.14 & 2.19 & 0.18 & 0.21 & 3.14 & 3.02 \\
\hline$\left(\mathrm{T}_{3}\right) 75 \% \mathrm{RD}+14 \mathrm{~kg}$ compost $+5 \mathrm{ml}$ bio./plant & 19.87 & 17.94 & 2.26 & 2.37 & 0.21 & 0.24 & 3.29 & 3.25 \\
\hline ( $\left.\mathrm{T}_{4}\right) 75 \% \mathrm{RD}+21 \mathrm{~kg}$ compost $+5 \mathrm{ml}$ bio./plant & 20.94 & 19.65 & 2.43 & 2.56 & 0.23 & 0.26 & 3.56 & 3.41 \\
\hline ( $\left.\mathrm{T}_{5}\right) 75 \% \mathrm{RD}+15 \mathrm{~g}$ humic $+5 \mathrm{ml}$ bio./plant & 19.43 & 17.83 & 2.21 & 2.29 & 0.19 & 0.23 & 3.26 & 3.24 \\
\hline ( $\left.\mathrm{T}_{6}\right) 75 \% \mathrm{RD}+30 \mathrm{~g}$ humic $+5 \mathrm{ml}$ bio./plant & 19.81 & 18.94 & 2.29 & 2.31 & 0.20 & 0.25 & 3.25 & 3.21 \\
\hline ( $\left.\mathrm{T}_{7}\right) \mathbf{7 5} \% \mathrm{RD}+45 \mathrm{~g}$ humic $+5 \mathrm{ml}$ bio./plant & 20.64 & 19.23 & 2.41 & 2.52 & 0.22 & 0.26 & 3.52 & 3.39 \\
\hline L.S.D at $0.05 \%$ & 1.82 & 1.61 & 0.43 & 0.45 & 0.056 & 0.071 & 0.27 & 0.38 \\
\hline
\end{tabular}

The obtained results of leaf chemical composition of Grande Naine banana plants are in harmony with the findings of Abd El-Naby (2000), Abd El-Naby and Gomaa (2000), Alvarez et al., (2001),
Hammam et al., (2003), Solimanm et al., (2006), Baiea and El-Gioushy (2015), Amin et al., (2016) and Rajput et al., (2017) on different banana cultivars. In this concern, Abdel Gawad-Nehad 
(2016) on Grande Naine banana mentioned that leaf $\mathrm{N}$ and $\mathrm{K}$ contents were significantly affected by compost tea applications, the plant which received $80 \%$ NPK plus organic fertilizers (compost tea 20 $\mathrm{kg} / 100 \mathrm{~L}+$ humic acid $5 \mathrm{~g} / \mathrm{L}$ ) gave the highest leaf $\mathrm{N}$ and $\mathrm{K}$ contents when compared with other treatments.

The gained results of this study may be due to the role of fertilization in growth and development of banana plants; hence the use of organic fertilizers (compost or humic acid) added to the soil, it led to decrease soil $\mathrm{pH}$ which led to increase solubility of the nutrients for plant uptake, in some cases organic materials may act as low release fertilizer. Recently, on the way of sustainable agriculture with minimum effects, the use of organic fertilization (compost or humic acid,... etc) as natural soil amendments is recommended to substitute the soluble chemical fertilizers. They enhance the structure of weakstructured sandy soils and improve their water holding capacity. Also, they increase soil fertility, and activate root growth, create active biological conditions and enhancing activities of microorganisms, especially those related with mineralization (Suresh et al., 2004). Furthermore, to interpret and evaluate the influence of chemical fertilization of this work, on increasing the different studied vegetative growth criteria, yield and chemical composition of banana plants, it is important to refer to the physiological roles of nitrogen, phosphorus and potassium in plant growth and development. Such three macronutrient elements are the basic elements usually used in chemical fertilizers. Plant supplement with these macronutrients in form of fertilizers is necessary because the soil is usually in deficient of them due to plant removal leaching or they are not readily available for plants (Marschener, 1997). Therefore, such addition of NPK fertilization quantities insured production of high productivity and chemical composition of banana plants.

\section{References}

A.O.A.C "Association of Official Agricultural Chemists" (1995). Official Methods of Analysis pub. chapter (37): 1-32 and chapter (45): 16-19. Inter. Suite 4002200 Wilson Boulevard Arlingtion, Virginia 22201-3301. USA.

Abd El-Moneim-Eman, A. A.; A. S. E. Abd-Allah and M. A. Ahmed (2008). The combined effect of some organic manures, mineral $\mathrm{N}$ fertilizers and algal cells extract on yield and fruit quality of Williams banana plants. American-Eurasian J. Agric. \& Environ. Sci., 4 (4): 417-426.

Abd El-Naby, S. K. M. (2000).Effect of banana compost as organic manure on growth, nutrients status, yield and fruit quality of Maghrabi banana. Assiut J. Agric. Sic., 3:101-114.
Abd El-Naby, S. K. M. and A. M. Gomaa (2000). Growth, nutritional status, yield and fruit quality of Maghrabi banana as affected by some organic manures and bio-fertilizers. Minufiya J. of Agric. Res. 25(4): 1113- 1129.

Abd El-Naby, S. K. M. and M. R. El Sonbaty (2005). Effect of partial replacement of chemical fertilizers by organic manures in banana production and fruit quality. Assiut J. Agric. Sic., 36:107-122.

Abdel Gawad-Nehad, M. A. (2016). Effect of organic compost tea and humic acid to reduce dose of NPK fertigation of banana plants cv. "Grand Nain". Egypt. J. Hort. 43 (2): 195-210.

Abdelaal, S. H.; E. Mohamed and S.S. Kabeil (2010). Microbial bio-fertilization approaches to Improve yield and quality of Washington navel orange and reducing the survival of nematode in the soil; J. American Sci., 6(12): 264-272.

Al-Busaidi, K. T. S. (2013). Effects of organic and inorganic fertilizers addition on growth and yield of banana (Musa AAA cv. Malindi) on a saline and non-saline soil in Oman. J. Hort. For. , 5(9): 146-155.

Alvarez, C.E.; A. Ortega; M. Fermandez and A.A. Borges (2001). Growth, yield and leaf nutrient content of organically grown banana plants in the Canary Islands. Fruits, 56(1): 17-26.

Amin, O. A.; M. A. Abdel Gawad-Nehad; E. Hala-Emam and A. A. Abd El- MoneimEman (2016). Effect of soil application with humic and amino acid on vegetative growth, nutritional statues, yield and fruit quality of Grande Naine banana plants. International Journal of PharmTech Research, 9(12): 88-96.

Athani, S. I. and N.C. Hulamani (2000). Effect of vermicompost on fruit yield and quality of banana cv. Rajapuri (Musa AAB). Karnataka J. Agri. Sci., 13(4): 942-946.

Ayuso, F. (2002). Effect of organic amendments and a mycorrhizal fungus on Radopholussimilisin banana (Musa AAA cv. Valery). Manejo Intergrado de. Plagas Y Agroecologia, 65: 8291.

Baiea, M.H.M. and S. F. EL-Gioushy (2015). Effect of some different sources of organic fertilizers in presence of bio-fertilizer on growth and yield of banana cv. Grande Naine plants. Middle East J. Agric. Res., 4(4): 745-753.

Bakheit, I. and E.H. El-sadig (2015). Effect of organic and chemical fertilizers on yield and total soluble solids (TSS) in Banana Cavendish group (AAA). Journal of Horticulture and Forestry, 7 (4): 94-98.

Barakat, M. R.; S. El-Kosary and M. H. AbdEINafea (2011). Enhancing Williams banana cropping by using some organic fertilization treatments. Journal of Horticultural Science \& Ornamental Plants 3(1): 29-37. 
Brown, J. D. and O. Lilleland (1946). Rapid determination of potassium and sodium in plant material and soil extract by flame photometry. Proc. Amer. Hort. Sci., 48: 341-346.

Coker, C. (2006). Environmental remediation by composting. Biocycle, 47, 18-23.

Damatto-Junior, E.R.; R.L.V. Boas and S. Leonel (2007). Influence of fertilization with organic compost in plant growth, development and production of banana 'Prata-Ana' (Musa AAB). Energia-na-Agricultura. 22 (2), 27-37.

Eissa-Fawzia, M.; M.A. Faith and S.A. El-Shall (2007). The role of humic acid and rootstock in enhancing salt tolerance of "Le-Conte" pear seedlings. J. Agric. Sci. Mansoura Univ., 32(5): 3651-3666.

EL-Agamy, M. K. F.; M. A. Abd EL-GawadNahad and E. S. Boshra (2001). Effect of different levels of humic acid and water quantities on the vegetative parameters and yield characteristics in Grand Naine banana plants. Egypt. J. of Applied Sci., 26(12B): 378389.

El-Sawy, Y.A.E. (2005). Studies on the effect of some organic fertilizers, ammonium nitrate and the bio-fertilizers (Algae extract) on growth and productivity of Williams banana (Musa cavendishii L). M.Sc. Thesis Fac. Agric. Qena, South Valley Univ. Egypt.

El-Shenawi, M. R.; H.S. Aly and B. A. F. Mohamed (2008). Response of "Grandnain" banana to humic acid, potassium and magnesium fertilization. Alexandria Science Exchange Journal, 29: 244-251.

Evenhuis, V. and P. W. Dewaored (1980). Principles and practices in plant analysis. FAO Soils Bull. 38(1): 152-163.

Gogoi, D.; U. Kotoky and S. Hazarika (2004). Effect of biofertilizers on productivity and soil characteristics in banana. Indian Journal of Horticulture. 61(4): 354-356.

Gowen, S. (1995). Banana and plantains. Chapman \& Hall London P.597.

Hammam, M. S.; E. G. Ibrahim and A. E. M. Mansour (2003). Response of Williams banana to some organic nitrogen fertilizers. Egypt J. Hort., 30: 51-65.

Hema, R.; B. V. K. Bhagavan; V. Sudhavani and K. Umakrishna (2016). Effect of organic manures and bio-fertilizers on yield and fruit quality of banana cv. Grand Naine (Musa AAA). International Journal of Bio-resource and Stress Management, 7(4):832-836.

Herbert, D.; P. J. Phipps and R. E. Strange (1971). Determination of total carbohydrates, Methods in Microbiology, 5 (8): 290-344.

Hewitt, C.W. (1955). Leaf analysis as a guide to the nutrition of banana. Emp J. exp. Agric., 23: 1116.
Hui, Y.H.; J. Barta; M. P. Cano; T. W. Gusek; J. S. Sidhu and N. K. Sinha (2006). Handbook of Fruits and Fruit Processing. Wiley- Blackwell, USA.

Ibrahim, E. G. (1993). Studies on irrigation of banana. Ph. D. Thesis, Fac. Agri. Zagazig Univ.

Ismail, A. F.; S. M. Hussien; S. A. El-Shall and M.A. Fathi (2007). Effect of irrigation and humic acid on Le-Conte pear. J. Agric. Sci. Mansoura Univ., 32(9): 7589-7603.

Marschner, H. (1997). Mineral Nutrition of Higher Plants. 2nd ed. San Diego: Academic Press, 379-396.

Murry, D.B. (1960). Deficiency symptoms of the major elements in the banana. Trop. Agric. Trim. 36:100-107.

Nardi, S., Tosoni, M., Pizzeghello, D., Provenzano, M.R., Cilenti, A., Sturaro, A., Rella, R. and Vianello, A. (2005). Chemical characteristics and biological activity of organic substances extracted from soils by root exudates. Soil Science Society of America Journal, 69, 20122019. http://dx.doi.org/10.2136/sssaj2004.0401.

Nolin, J. (1985). Stage of maturity of banana (cv. Giant Cavendish) at harvest a new measuring method. Fruits, 40(10): 623-631.

National campaign for improving banana productivity in Egypt (2014). (In Arabic).

Park, B.; A. Shin; S. K. Park; K. P. Ko; S.H. Ma; E.H. Lee; J. Gwack and E.J. Jung (2011). Ecological study for refrigerator use, salt, vegetable, and fruit intakes and gastric cancer. Cancer Causes Control, 22: 1497-1502.

Pregl, E. (1945). Quantitative Organic Micro Analysis 4th Ed. Chundril, London.

Rajput, A.; M. Memon; K. S. memon; S. Tunio; T. A. Sial and M.A. Khan (2017). Nutrient composition of banana fruit as affected by farm manure, composted press mud and mineral fertilizers. Pak. J. Bot., 49(1): 101-108.

Russo, R.O. and G.P. Berlyn (1990). The use of organic biostimulants to help low input sustainable agriculture. J. Sustainable Agric., 1(2):19-42.

Sangeeta, B. H.; A. M. Shorol; H. Suresh; G. S. Lenkennavar; K. Swamy; M. D. Shashidhar and S. Basur (2017). Effect of organic manures on yield and quality of banana cv. Grand Naine.Int. J. Pure App. Biosci. 5 (6): 1094-109.

Sharrock, S. L.; J.P. Horry and E.A. Frison (2001). The state of the use of Musa diversity. In: Cooper HD, Spillane C, Hodgkin T (eds.), Broadening the Genetic Base of crop Production. IPGRI/FAO.P 223.

Snedecor, W. and W.G. Cochran (1980). Statistical Methods, 7th ed. Iowa State Univ. Press Ames. Iowa. U.S.A.

Solimanm, S. S.; M. R. EL-Sonbaty and M. A. Ahmed (2006). Effect of organic manures 
sources on growth yield, fruit quality and some minerals content of Maghrabi banana.Minufiya. J. Agric. Res., 31(5):1173-1197.

Suresh, C. P. and M. A. Hasan (2001). Studies on the response of Dwarf Cavendash banana (Musa AAA) to biofertilizer inoculation. Horticultural Journal. 14(1): 35-41.

Suresh, K. D.; G. Sneh; K. K. Krishn and C. M. Mool (2004). Microbial biomass carbon and microbial activities of soils receiving chemical fertilizers and organic amendments. Arch. Agron. Soil Sci., 50: 641-647.
Tirkey, T.; S. Agrawal and S.D. Pandey (2002). Effect of organic manures on growth, maturity and yield of banana cv. Dwarf Cavendish.South Indian Horticulture, 50(1): 19-24.

Vazquez-Ovando, J. A.; D. K. Andrino-Lopez; M. D. L. Adriano-Anaya; M. SalvadorFigueroa; I. Ovando-Medina (2012). Sensory and physic-chemical quality of banana fruits (Grande Naine) grown with biofertilizer. African J. of Agric., Res. 7 (33): 4620-4626.

Zaccardelli, M.; C. Pane; R. Scotti; A. M. Palese and G. Celano (2012). Use of compost-tea as bio-agrochemicals and bio-stimulants in horticulture. ItalusHortus, 19: 17-28.

\section{تأثير بعض معاملات التسميد على النمو والمحصول وجودة الثمار والحالة الغذائية لصنف الموز جراندنان حامد الزعبلاوي محمود البدوي 1، مها محمد السيد على 2

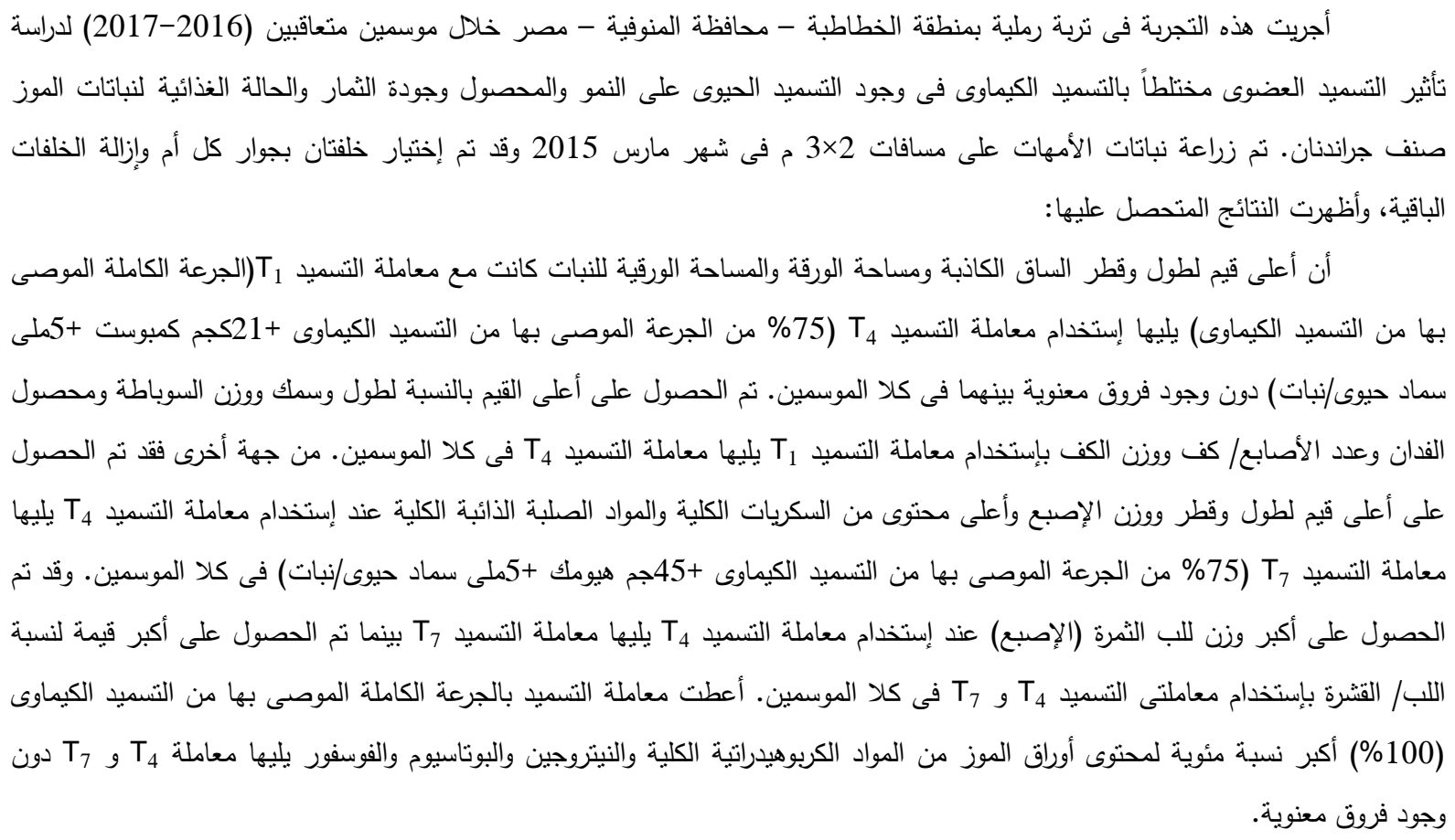

